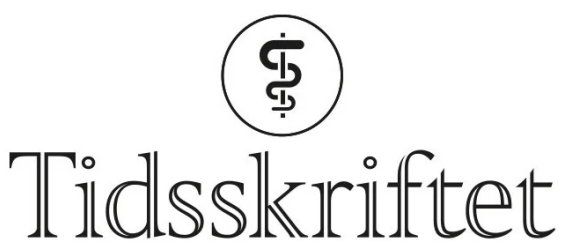

\title{
Hva betyr tidligere hjerte- og karsykdom eller kreft for risiko for død etter påvist SARS-CoV-2?
}

ORIGINALARTIKKEL

\section{RUNE KVÅLE}

rune.kvale@fhi.no

Avdeling for helseregisterforskning og-utvikling

Folkehelseinstituttet, Bergen

og

Avdeling for kreftbehandling og medisinsk fysikk

Haukeland universitetssjukehus

Han har bidratt med idé og design, analyser av data, tolking av resultater, litteratursøk, utarbeiding og revisjon av manuset og godkjenning av innsendte manusversjon.

Rune Kvåle er ph.d., spesialist i onkologi og overlege.

Forfatteren har fylt ut ICMJE-skjemaet og oppgir ingen interessekonflikter.

\section{KAARE HARALD BØNAA}

Klinikk for hjertemedisin

St. Olavs hospital, Trondheim

og

Institutt for sirkulasjon og bildediagnostikk

Norges teknisk-naturvitenskapelige universitet

Han har bidratt med idé til analyser, tolking av resultater, utarbeiding og revisjon av manuset og godkjenning av innsendte manusversjon.

Kaare Harald Bønaa er ph.d., spesialist i indremedisin og i hjertemedisin og er professor. Han har klinisk spesialkompetanse innen invasiv kardiologi og forskningserfaring innen epidemiologi og randomiserte multisenterstudier.

Forfatteren har fylt ut ICMJE-skjemaet og oppgir ingen interessekonflikter.

\section{RACHEL FORSTER}

Avdeling for helseregisterforskning og -utvikling

Folkehelseinstituttet, Bergen

Hun har bidratt med design, litteratursøk, utarbeiding og revisjon av manuset og godkjenning av innsendte manusversjon.

Rachel Forster er ph.d. og har spesialkompetanse i epidemiologi innenfor kroniske sykdommer,

inkludert hjerte- og karsykdommer.

Forfatteren har fylt ut ICMJE-skjemaet og oppgir ingen interessekonflikter.

\section{KIRSTEN GRAVNINGEN}

Avdeling for smittevern og beredskap

Folkehelseinstituttet, Oslo 
Hun har bidratt med tolking av resultater, litteratursøk, utarbeiding og revisjon av manuset og godkjenning av innsendte manusversjon.

Kirsten Gravningen er ph.d., spesialist i medisinsk mikrobiologi og overlege.

Forfatteren har fylt ut ICMJE-skjemaet og oppgir ingen interessekonflikter.

\section{PÉTUR BENEDIKT JÚLÍUSSON}

Avdeling for helseregisterforskning og -utvikling

Folkehelseinstituttet, Bergen

og

Barne- og ungdomsklinikken

Haukeland universitetssjukehus

og

Klinisk institutt 2

Universitetet i Bergen

Han har bidratt med tolking av resultater, utarbeiding og revisjon av manuset og godkjenning av innsendte manusversjon.

Pétur Benedikt Júlíusson er ph.d., avdelingsdirektør, overlege og professor. Han har spesialkompetanse i pediatrisk endokrinologi.

Forfatteren har fylt ut ICMJE-skjemaet og oppgir ingen interessekonflikter.

\section{TOR ̊̊GE MYKLEBUST}

Registeravdelingen

Kreftregisteret, Oslo

og

Seksjon for forskning og innovasjon

Helse Møre og Romsdal, Ålesund

Han har bidratt med design, analyser, tolking av resultater, utarbeiding og revisjon av manuset og godkjenning av innsendte manusversjon.

Tor Åge Myklebust er ph.d, forsker og statistiker. Han jobber med registerbasert forskning generelt, men med et hovedfokus på kreftepidemiologi og statistiske metoder knyttet til overlevelse.

Forfatteren har fylt ut ICMJE-skjemaet og oppgir ingen interessekonflikter.

\section{BAKGRUNN}

Hjerte- og karsykdommer og kreft har vært beskrevet som mulige risikofaktorer for død av covid-19. Hensikten med studien er å undersøke om tidligere påvist hjerte- og karsykdom eller kreft har påvirket risiko for å dø etter påvist covid-19 i Norge.

\section{MATERIALE OG METODE}

Data fra Meldingssystem for smittsomme sykdommer, Nasjonalt register over hjerte- og karsykdommer og Kreftregisteret ble sammenstilt. Bi- og multivariable regresjonsmodeller ble brukt for å beregne både relativ og absolutt risiko.

\section{RESULTATER}

Første halvår 2020 fikk 8809 personer påvist SARS-CoV-2 og 260 covid-19-assosierte dødsfall ble registrert. Økende alder, mannlig kjønn (relativ risiko (RR): 1,5; konfidensintervall (KI): 1,2 til 2,o), tidligere hjerneslag (RR: 1,5; KI: 1,o til 2,1) og kreft med fjernspredning på diagnosetidspunktet (RR:3,0; KI: 1,1 til 8,2) var uavhengige risikofaktorer for død etter påvist covid-19. Etter justering for alder og kjønn var hjerteinfarkt, atrieflimmer, hjertesvikt, hypertensjon og ikke-metastatisk kreft ikke lengre statistisk signifikante risikofaktorer for $\mathrm{d} ø \mathrm{~d}$.

\section{FORTOLKNING}

Den største risikofaktoren for død blant SARS-CoV-2-testpositive personer var alder. Mannlig kjønn, tidligere påvist hjerneslag og kreft med fjernspredning var også assosiert med forhøyet risiko for død etter påvist covid-19. 
I tillegg til økende alder og mannlig kjønn, var tidligere påvist hjerneslag og kreft med fjernspredning på diagnosetidspunktet forbundet med større risiko for død etter påvist covid-19.

Hjerte- og karsykdommer og kreft har tidligere vært beskrevet som mulige risikofaktorer for alvorlig sykdom og død grunnet covid-19 (1,2). I tillegg til komorbiditet har tidligere publiserte studier også vist at økende alder og mannlig kjønn er assosiert med høyere risiko for $\mathrm{d} ø \mathrm{~d}(3 \underline{-6})$. I mange studier har man undersøkt hvordan risiko for død påvirkes av komorbiditet hos innlagte pasienter på sykehus eller etter oppfølging av pasienter identifisert i allmennpraksis. Disse studiene inneholder selekterte pasientgrupper og er utført i land med helseregistre av varierende kvalitet. Bortsett fra en nylig publisert studie fra Danmark (므), er det få studier der man har undersøkt risikofaktorer for død basert på populasjonsbaserte data.

En oversikt over letalitet i ulike aldersgrupper og risikotilstander blant personer som døde etter påvist SARS-CoV-2 i Norge, er nylig publisert i Tidsskriftet (7.). I denne studien har man ikke undersøkt betydningen av tidligere påviste sykdommer for risiko for $\mathrm{d} ø \mathrm{~d}$. Vi ønsket derfor å bruke nasjonale helseregisterdata for å undersøke om tidligere påvist hjerte- og karsykdom eller kreft påvirket risiko for å dø etter positiv test for SARS-CoV-2 første halvår 2020.

\section{Materiale og metode}

\section{DATAKILDER}

I studien har vi benyttet data fra Meldingssystem for smittsomme sykdommer (MSIS), Nasjonalt register over hjerte- og karsykdommer (Hjerte- og karregisteret) og Kreftregisteret. Informasjon fra Meldingssystem for smittsomme sykdommer ble koblet med data fra Hjerte- og karregisteret og Kreftregisteret ved hjelp av et felles prosjektspesifikt løpenummer for de tre registrene. Kun data på gruppenivå ble utlevert og analysert.

Fra MSIS identifiserte vi alle individer som hadde testet positivt for SARS-CoV-2 ved polymerasekjedereaksjonstest (PCR) i løpet første halvår 2020 (uttrekk utført 30.6.2020). Vi fikk informasjon om alle covid-19-assosierte dødsfall blant disse (oppdatert 4.12.2020).

Dødsfall etter påvist covid-19 som er meldt til MSIS eller Dødsårsaksregisteret, samt alle dødsfall i løpet av de første zo dagene etter positiv SARS-CoV-2-test, registreres som covid19-assosierte. Dette betyr at covid-19-assosierte dødsfall omfatter dødsfall der personen dør av covid-19 og noen tilfeller der personen dør med covid-19. Ved en gjennomgang utført i Dødsårsaksregisteret var covid-19 underliggende dødsårsak for over $91 \%$ av de meldte covid-19-assosierte dødsfallene (모).

Hjerte- og karregisteret består av et basisregister (Basisregisteret) og åtte tilknyttede kvalitetsregistre. Basisregisteret inneholder opplysninger om polikliniske konsultasjoner og sykehusopphold for pasienter med hjerte- og karsykdommer hentet fra Norsk pasientregister, opplysninger om dødsfall hentet fra Dødsårsaksregisteret samt administrative data fra Folkeregisteret. Tidligere hjerte- og karsykdom (hjerneslag, hjerteinfarkt, atrieflimmer, hjertesvikt og hypertensjon nevnt som hoved- eller bidiagnose ved sykehusopphold) og opplysninger om annen komorbiditet blant testpositive ble hentet fra Basisregisteret for perioden 2012-19 (tabell 1). Basisregisteret har kun informasjon om andre sykdommer fra samme opphold/episode som det foreligger en hjerte- og karrelatert diagnose, og opplysningene om andre sykdommer enn hjerte- og karsykdommer er derfor ufullstendige. 


\section{Tabell 1}

Datakilder og definisjoner av sykdommer benyttet i studien.

\begin{tabular}{|c|c|c|}
\hline Datakilder (periode) & Sykdom & Inklusjonskriterier \\
\hline $\begin{array}{l}\text { Meldingssystem for } \\
\text { smittsomme } \\
\text { sykdommer (1. og } 2 . \\
\text { kvartal 2020) }\end{array}$ & Covid-19 & SARS-CoV-2-testpositive tilfeller \\
\hline $\begin{array}{l}\text { Kreftregisteret } \\
(2010-19)\end{array}$ & Kreft & All kreft utenom non-melanom hudkreft \\
\hline \multirow[t]{14}{*}{$\begin{array}{l}\text { Hjerte- og karregisteret }{ }^{1} \\
(2012-19)\end{array}$} & \multicolumn{2}{|l|}{$\begin{array}{l}\text { Hjerte- og } \\
\text { karsykdommer }\end{array}$} \\
\hline & Akutt hjerneslag & $161,163,164$ \\
\hline & Akutt hjerteinfarkt & $121-122$ \\
\hline & Atrieflimmer & 148 \\
\hline & Hjertesvikt & I11.0, I13.0, I13.2, I50.0, I50.1, I50.9 \\
\hline & Hypertensjon & $|10-| 15$ \\
\hline & \multicolumn{2}{|l|}{$\begin{array}{l}\text { Annen } \\
\text { komorbiditet }^{2}\end{array}$} \\
\hline & Astma & $\mathrm{J} 45, \mathrm{~J} 46$ \\
\hline & Demens $^{3}$ & F00-F03, G30, G31.0 G31.2, G31.8 \\
\hline & Diabetes type 1 & E10 \\
\hline & Diabetes type 2 & E11 \\
\hline & $\begin{array}{l}\text { Kronisk obstruktiv } \\
\text { lungesykdom (kols) }\end{array}$ & $\mathrm{J} 43, \mathrm{~J} 44$ \\
\hline & Fedme $^{4}$ & E66 \\
\hline & Nyresvikt & N18.3-N18.5 \\
\hline
\end{tabular}

${ }^{1}$ Alle hoved- eller bidiagnoser (ICD-10-koder)

${ }^{2}$ Diagnoser registrert i tillegg til en hjerte- og karrelatert diagnose i Hjerte- og karregisteret ${ }^{3}$ Hjerte- og karregisteret inneholder alle registrerte med vaskulær demens (Fo1)

${ }^{4}$ Kroppsmasseindeks $\geq 30 \mathrm{~kg} / \mathrm{m}^{2}$

Fra Kreftregisteret fikk vi data på all kreft (utenom non-melanom) med opplysninger om stadium (lokalisert eller regional sykdom, fjernspredning) for perioden 2010-19. For pasienter med kreft hadde vi informasjon om hjerte- og karsykdommer og eventuell annen komorbiditet fra Hjerte- og karregisteret.

\section{STATISTISKE METODER}

Ujustert og justert relativ risiko for aldersgruppene $<60,60-69,70-79,80-84,85-89$ og $>90$ samt for de inkluderte sykdommene ble estimert ved hjelp av bi- og multivariable Poissonregresjonsanalyser. Alle analyser er utført i STATA (versjon 15.0). I de multivariable analysene estimerte vi to forskjellige regresjonsmodeller. 
I modell 1 har vi justert for alder og kjønn, og den inneholder aldersgrupper, kjønn, hjerteog karsykdommer og kreft. Modell 2 justerer for alder, kjønn, hjerte- og karsykdommer, kreft og tilgjengelige opplysninger om annen komorbiditet (astma, demens, diabetes, fedme, kols, nyresvikt). I denne modellen har vi også estimert tallene etter å ha tatt bort personer over 84 år, som oftere har multimorbiditet, en generelt forhøyet risiko for $\mathrm{d} ø \mathrm{~d}$ og større sannsynlighet for feilklassifisering av dødsårsak.

For å supplere de relative estimatene med absolutte tall regnet vi ut sannsynligheter for $\mathrm{d} ø \mathrm{~d}$ basert på en multivariabel logistisk regresjonsanalyse med samme kovariater som i modell 2.

ETIKK

Vi fikk tilrettelagt statistikk hjemlet i forskriftene for registrene. Det var ikke tilgang til fødselsnummer eller andre direkte personidentifiserende kjennetegn, og vi fikk kun utlevert data aggregert i forhåndsdefinerte grupper.

\section{Resultater}

I løpet av første halvår 2020 fikk 8809 personer påvist SARS-CoV-2 i Norge, og blant disse er 26o covid-19-assosierte dødsfall registrert. 7705 (87\%) av de testpositive og 34 (13\%) av dødsfallene var hos personer under 70 år. Av de diagnostiserte (letalitet) med SARS-CoV-2 i denne perioden var den totale prosentandelen som døde på 3,o, og varierte fra $0,2 \%$ for personer under 60 år til 57,6 \% for personer 90 år og eldre (tabell 2). Hypertensjon var den hyppigst forekommende tidligere registrerte tilstanden blant hjerte- og karsykdommene, både blant de diagnostiserte (645(7,3\%)) og blant de døde (95 (36,5\%)). Kreft var tidligere påvist hos 372 (4,2\%) av de testpositive og hos $36(13,9 \%)$ av de døde.

\section{Tabell 2}

Pasientkarakteristika og letalitet (prosentandel døde av de diagnostiserte) for tilfeller med positiv test for sars-CoV-2 fra første halvår 2020. Resultatene angis som antall (\%) dersom annet ikke er angitt.

\begin{tabular}{|c|c|c|c|}
\hline & Testpositive tilfeller & Dødsfall & Letalitet \\
\hline Totalt & $8809(100)$ & $260(100)$ & 3,0 \\
\hline \multicolumn{4}{|l|}{ Alder } \\
\hline$<60$ år & $6787(77,0)$ & $12(4,6)$ & 0,2 \\
\hline 60-69 år & $918(10,4)$ & $22(8,5)$ & 2,4 \\
\hline 70-79 år & $603(6,8)$ & $59(22,7)$ & 9,8 \\
\hline 80-84 år & $221(2,5)$ & $43(16,5)$ & 19,5 \\
\hline 85-89 år & $155(1,8)$ & $52(20,0)$ & 33,6 \\
\hline$>90$ år & $125(1,4)$ & $72(27,7)$ & 57,6 \\
\hline \multicolumn{4}{|l|}{ Kjønn } \\
\hline Kvinner & $4444(50,5)$ & $121(46,5)$ & 2,7 \\
\hline Menn & $4365(49,5)$ & $139(53,5)$ & 3,2 \\
\hline \multicolumn{4}{|l|}{ Hjerte- og karsykdommer } \\
\hline Tidligere hjerneslag & $125(1,4)$ & $34(13,1)$ & 27,2 \\
\hline
\end{tabular}




\begin{tabular}{|c|c|c|c|}
\hline & Testpositive tilfeller & Dødsfall & Letalitet \\
\hline Tidligere hjerteinfarkt & $109(1,2)$ & $16(6,2)$ & 14,7 \\
\hline Atrieflimmer & $300(3,4)$ & $59(22,7)$ & 19,7 \\
\hline Hjertesvikt & $155(1,8)$ & $29(11,2)$ & 18,7 \\
\hline Hypertensjon & $645(7,3)$ & $95(36,5)$ & 14,7 \\
\hline \multicolumn{4}{|l|}{ Kreft } \\
\hline Totalt & $372(4,2)$ & $36(13,9)$ & 9,7 \\
\hline Lokalisert/regional sykdom & $284(3,2)$ & $25(9,6)$ & 8,8 \\
\hline Metastatisk ${ }^{1}$ sykdom & $18(0,2)$ & $4(1,5)$ & 22,2 \\
\hline Ukjent stadium & $70(0,8)$ & $7(2,7)$ & 10,0 \\
\hline \multicolumn{4}{|l|}{ Annen komorbiditet ${ }^{2}$} \\
\hline Astma & $40(0,5)$ & $5(1,9)$ & 12,5 \\
\hline Demens & $73(0,8)$ & $38(14,6)$ & 52,1 \\
\hline Diabetes type I & $11(0,1)$ & $2(0,8)$ & 18,2 \\
\hline Diabetes type II & $155(1,8)$ & $33(12,7)$ & 21,3 \\
\hline Fedme & $39(0,4)$ & $3(1,2)$ & 7,7 \\
\hline Kols & $55(0,6)$ & $14(5,4)$ & 25,5 \\
\hline Nyresvikt & $57(0,7)$ & $18(6,9)$ & 31,6 \\
\hline Minst én av sykdommene nevnt over & $1214(13,8)$ & $162(62,3)$ & 13,3 \\
\hline
\end{tabular}

${ }^{1}$ Ved diagnosetidspunkt

${ }^{2}$ Diagnoser registrert i tillegg til en hjerte- og karrelatert diagnose i Hjerte- og karregisteret

Tidligere påvist kreft og de undersøkte hjerte- og kardiagnosene var alle assosiert med en signifikant forhøyet risiko for $\mathrm{d} ø \mathrm{~d}$ i de ujusterte analysene, med relativ risiko på mellom 3,3 for ikke-metastatisk kreft til 10,5 for hjerneslag (tabell 3, bivariable analyser). Etter justering for alder, kjønn og annen komorbiditet hadde pasienter med tidligere hjerneslag (RR:1,5; KI: 1,o til 2,1) og kreft med metastaser ved diagnose (RR:3,0; KI: 1,1 til 8,2) en signifikant forhøyet risiko for $\mathrm{d} ø \mathrm{~d}$.

\section{Tabell 3}

Risiko for død etter påvist covid-19 første halvår 2020. Bi- og multivariable analyser (RR = relativ risiko, $\mathrm{KI}=$ konfidensintervall).

\begin{tabular}{|c|c|c|c|c|}
\hline & \multirow{3}{*}{$\begin{array}{l}\text { Bivariable } \\
\text { analyser }\end{array}$} & \multicolumn{3}{|c|}{ Multivariable analyser } \\
\hline & & \multirow[t]{2}{*}{ Modell $1^{2}$} & \multicolumn{2}{|l|}{ Modell 23 } \\
\hline & & & $\begin{array}{l}\text { Alle } \\
\text { aldersgrupper }\end{array}$ & Alder $<85$ år \\
\hline Alder & $\mathrm{RR}(95 \% \mathrm{KI})$ & $\mathrm{RR}(95 \% \mathrm{KI})$ & RR (95 \% KI) & $\mathrm{RR}(95 \% \mathrm{KI})$ \\
\hline$<60$ år & Ref. & Ref & Ref. & Ref. \\
\hline
\end{tabular}




\begin{tabular}{|c|c|c|c|c|}
\hline & \multirow{3}{*}{$\begin{array}{l}\text { Bivariable } \\
\text { analyser }\end{array}$} & \multicolumn{3}{|c|}{ Multivariable analyser } \\
\hline & & \multirow{2}{*}{ Modell 1} & \multicolumn{2}{|l|}{ Modell 2} \\
\hline & & & $\begin{array}{l}\text { Alle } \\
\text { aldersgrupper }\end{array}$ & Alder $<85$ år \\
\hline 60-69 år & $13,6(6,7$ til 27,4$)$ & $\begin{array}{r}13,3 \\
(6,6 \text { til } 26,9)\end{array}$ & $13,1(6,5$ til 26,6$)$ & $\begin{array}{r}12,5 \\
(6,2 \text { til } 25,3)\end{array}$ \\
\hline 70-79 år & $\begin{array}{r}55,3 \\
(29,7 \text { til } 102,9)\end{array}$ & $\begin{array}{r}54,5 \\
(29,3 \text { til } 101,4)\end{array}$ & $51,0(27,2$ til 95,7$)$ & $\begin{array}{r}45,1 \\
(23,7 \text { til 85,6) }\end{array}$ \\
\hline 80-84 år & $\begin{array}{r}110,0 \\
(58,0 \text { til } 208,7)\end{array}$ & $\begin{array}{r}114,3 \\
(60,2 \text { til } 216,8)\end{array}$ & $\begin{array}{r}105,4 \\
(54,9 \text { til } 202,1)\end{array}$ & $\begin{array}{r}81,3 \\
(41,1 \text { til } 160,8)\end{array}$ \\
\hline 85-90 år & $\begin{array}{r}189,7 \\
(101,3 \text { til } 355,4)\end{array}$ & $\begin{array}{r}193,4(103,2 \text { til } \\
362,2)\end{array}$ & $\begin{array}{r}178,4 \\
(93,8 \text { til } 339,5)\end{array}$ & - \\
\hline > 90 år & $\begin{array}{r}325,8 \\
(176,8 \text { til } 600,2)\end{array}$ & $\begin{array}{r}345,8 \\
(187,4 \text { til } 637,8)\end{array}$ & $\begin{array}{r}306,4 \\
(163,0 \text { til } 575,8)\end{array}$ & - \\
\hline Menn (ref. kvinner) & $1,2(0,9$ til 1,5$)$ & $1,5(1,2$ till, 9$)$ & $1,5(1,2$ til 2,0$)$ & $1,7(1,2$ til 2,4$)$ \\
\hline \multicolumn{5}{|l|}{$\begin{array}{l}\text { Hjerte- og } \\
\text { karsykdommer }^{1}\end{array}$} \\
\hline Hjerneslag & $10,5(7,3$ til 15,0$)$ & $1,5(1,1$ til 2,2$)$ & $1,5(1,0$ til 2,1$)$ & $\begin{array}{r}1,8(0,9 \text { til } \\
3,3)\end{array}$ \\
\hline Hjerteinfarkt & $5,2(3,2$ til 8,7$)$ & $0,9(0,6$ til 1,6$)$ & $0,8(0,4$ til 1,3$)$ & $\begin{array}{r}0,7(0,3 \text { til } \\
1,6)\end{array}$ \\
\hline Atrieflimmer & $8,3(6,2$ til 11,1$)$ & $1,3(0,9$ til 1,7$)$ & $1,2(0,8$ til 1,6$)$ & $\begin{array}{r}1,2(0,7 \text { til } \\
2,0)\end{array}$ \\
\hline Hjertesvikt & $7,0(4,8$ til 10,3$)$ & $1,2(0,8$ til 1,8$)$ & $0,9(0,6$ til 1,4$)$ & $\begin{array}{r}0,9(0,5 \text { til } \\
1,8)\end{array}$ \\
\hline Hypertensjon & $7,3(5,7$ til 9,4$)$ & $1,2(0,9$ til 1,5$)$ & $0,9(0,7$ til 1,2$)$ & $0,7(0,4$ til 1,1$)$ \\
\hline \multicolumn{5}{|l|}{ Kreft $^{1}$} \\
\hline $\begin{array}{l}\text { Lokalisert/regional } \\
\text { sykdom }\end{array}$ & $3,3(2,2$ til 5,0$)$ & $0,8(0,5$ til 1,2$)$ & $0,8(0,5$ til 1,2$)$ & $\begin{array}{r}0,7(0,4 \text { til } \\
1,4)\end{array}$ \\
\hline Metastatisk ${ }^{1}$ sykdom & $8,4(3,1$ til 22,5$)$ & $2,6(1,0$ til 7,1$)$ & $3,0(1,1$ til 8,2$)$ & $\begin{array}{r}3,0(0,9 \text { til } \\
9,8)\end{array}$ \\
\hline Ukjent stadium & $3,8(1,8$ til 8,0$)$ & $1,1(0,5$ til 2,3$)$ & $1,1(0,5$ til 2,3$)$ & $\begin{array}{r}1,6(0,7 \text { til } \\
3,8)\end{array}$ \\
\hline
\end{tabular}

${ }^{1}$ Referanse: Personer uten den aktuelle sykdommen

${ }^{2}$ Modell 1: Justert for alder og kjønn

3Modell 2: Justert for alder, kjønn, hjerte- og karsykdommer, kreft og tilgjengelige opplysninger om annen komorbiditet (astma, demens, diabetes, fedme, kols, nyresvikt)

Mannlig kjønn (RR:1,5; KI: 1,2 til 2,0) var også forbundet med en signifikant forhøyet risiko for $\mathrm{d} ø \mathrm{~d}$ (tabell 3, modell 2). Atrieflimmer var assosiert med høyere risiko etter justering for alder, kjønn og annen komorbiditet, men sammenhengen var ikke statistisk signifikant. Våre analyser viste at risiko for død var signifikant forhøyet når demens, nyresvikt og diabetes mellitus type 2 var registrert i tillegg til hjerte- og karsykdom (data ikke vist). 
Etter at vi ekskluderte personer over 84 år, fant vi noe høyere risikoestimater for kjønn (RR: 1,7; KI: 1,2 til 2,4) og hjerneslag (RR: 1,8; KI: o,9 til 3,3) og noe lavere for aldersgruppene 6o69, 70-79 og 8o-84 år (tabell 3, modell $2<85$ år). Inklusjon av de gjenværende sykdomsgruppene spesifisert med ICD-10-koder under I-kapittelet (sykdommer i sirkulasjonssystemet) påvirket ikke våre resultater (data ikke vist).

Sammenlignet med referansegruppen (testpositive under 60 år) var relativ risiko for $\mathrm{d} ø \mathrm{~d}$ for aldersgruppene $60-69,70-79,80-84,85-89$ og $\geq 90$ henholdsvis ca. 13, 50, 100, 180 og 300 ganger større i analyser justert for kjønn, hjerte- og karsykdommer, kreft og annen komorbiditet (tabell 3, modell 2). Estimert absolutt risiko for død hos personer som ikke tidligere var registrert med noen av de underliggende tilstandene, $ø$ kte fra $0,17 \%$ for de under 60 år, til 53,7\% for gruppen 90 år og eldre (tabell 4).

\section{Tabell 4}

Estimert absolutt risiko (\%) før død etter påvist covid-19 første halvår 2020 for personer med tidligere hjerneslag eller metastatisk kreftsykdom ved diagnose og for personer etter påvist covid-19 uten tidligere hjerte- og karsykdommer, kreft og annen komorbiditet registrert i denne studien (kvinner, menn og begge kjønn samlet).

\begin{tabular}{|c|c|c|c|c|c|c|}
\hline & \multirow{2}{*}{$\begin{array}{l}\text { Begge } \\
\text { kjønn }{ }^{1}\end{array}$} & \multirow{2}{*}{$\begin{array}{l}\text { Kvinner/ } \\
\text { Menn }^{1}\end{array}$} & \multicolumn{2}{|c|}{ Hjerneslag $^{2}$} & \multicolumn{2}{|c|}{ Metastatisk kreft $^{2}$} \\
\hline & & & $\begin{array}{l}\text { Begge } \\
\text { kjønn }\end{array}$ & $\begin{array}{l}\text { Kvinner/ } \\
\text { Menn }\end{array}$ & Begge kjønn & $\begin{array}{l}\text { Kvinner/ } \\
\text { Menn }\end{array}$ \\
\hline < 60 år & 0,17 & $0,12 / 0,22$ & 0,31 & $0,22 / 0,40$ & 0,78 & $0,56 / 1,00$ \\
\hline 60-69 år & 2,1 & $1,5 / 2,7$ & 3,8 & $2,8 / 4,9$ & 8,9 & $6,6 / 11,3$ \\
\hline 70-79 år & 7,8 & $5,8 / 10,0$ & 13,3 & $10,0 / 16,7$ & 27,5 & $21,7 / 33,3$ \\
\hline 80-84 år & 16,1 & $12,2 / 20,1$ & 25,7 & $20,2 / 31,3$ & 45,9 & $38,7 / 53,2$ \\
\hline 85-89 år & 27,8 & $22,0 / 33,7$ & 40,9 & $33,9 / 48,0$ & 62,8 & $56,1 / 69,7$ \\
\hline > 90 år & 53,7 & $46,5 / 61,0$ & 67,6 & $61,2 / 74,0$ & 83,6 & $79,7 / 87,6$ \\
\hline Totalt & 2,5 & $2,0 / 3,1$ & 3,8 & $3,1 / 4,6$ & 6,8 & $5,7 / 8,0$ \\
\hline
\end{tabular}

${ }^{1}$ Forutsetter at ingen av sykdommene som er inkludert i studien, foreligger (basert på multivariabel logistisk regresjonsmodell med alle kovariater)

${ }^{2}$ Forutsetter at ingen av de andre sykdommene som er inkludert i studien, foreligger (basert på multivariabel logistisk regresjonsmodell med alle kovariater. Estimatene er for noen grupper basert på få tilfeller og er derfor basert på ekstrapolering fra modell)

For personer med påvist hjerneslag var estimert absolutt risiko for $\mathrm{d} ø \mathrm{~d}$ i forhold til personer uten hjerneslag forhøyet med o,14\% for de under 60 år og med 13,9\% for gruppen 90 år og eldre. Estimert absolutt risiko for $\mathrm{d} ø \mathrm{~d}$ for personer med påvist sykdom med metastaser på diagnosetidspunktet var i forhold til personer uten metastaser forhøyet med o,61\% for gruppen under 60 år og med 29,9\% for gruppen 90 år og eldre. Den absolutte risikoen for $\mathrm{d} ø \mathrm{~d}$ for menn sammenlignet med kvinner var forhøyet med o,10 \% for gruppen under 60 år, mens den var økt med 14,5\% for gruppen 9o år og eldre (tabell 4).

\section{Diskusjon}


I denne registerkoblingsstudien med data fra MSIS, Hjerte- og karregisteret og Kreftregisteret fra 8 8og SARS-CoV-2-testpositive personer fant vi at økende alder, mannlig kjønn, gjennomgått hjerneslag og kreft med fjernspredning på diagnosetidspunktet var assosiert med forhøyet risiko for død etter påvist covid-19. Tidligere diagnostisert hjerteinfarkt, atrieflimmer, hjertesvikt, hypertensjon og ikke-metastatisk kreft forekom hyppigere blant de som døde av covid-19 enn blant de diagnostiserte, men etter at vi tok hensyn til alder og kjønn i multivariable analyser, fant vi at sykdommene ikke lenger var statistisk signifikante risikofaktorer for $\mathrm{d} ø \mathrm{~d}$.

For personer som hadde gjennomgått hjerneslag på sykehus i perioden 2012-19, var risiko for å dø etter smitte av SARS-CoV-2 økt med $50 \%$ etter justering for alder, kjønn og andre sykdommer. Våre resultater bekrefter funn fra flere tidligere studier som har antydet en forhøyet risiko for $\mathrm{d} ø \mathrm{~d}$ hos pasienter med cerebrovaskulær sykdom (5,.9.). Gjennomgått slag kan medføre nedsatt funksjonstilstand og mindre muligheter for effekt av intensivbehandling. Det har også vært diskutert om personer med tidligere hjerneslag har en større risiko for å få vaskulære hendelser som følge av covid-19-induserte koagulopatier som fører til alvorlige komplikasjoner og høyere risiko for $\mathrm{d} ø \mathrm{~d}(9$.$) .$

Foruten hjerneslag viste ingen av de inkluderte hjerte- og karsykdommene statistisk signifikant forhøyet risiko for død i vår studie. Tidligere studier har vist noe sprikende resultater vedrørende risiko for død ved underliggende hjerte- og karsykdommer (10 $)$. Våre funn er på linje med resultater fra Danmark ( $(\underline{6})$, der man fant lavere risiko ved iskemisk hjertesykdom (OR o,7 (KI: o,5 til o,9)) og hypertensjon (OR o,6 (KI: 0,5 til o,8)) etter justering for alder, kjønn og antall komorbiditeter.

Som i vår studie fant man i denne studien ingen signifikant $ø$ kt risiko ved atrieflimmer og hjertesvikt, mens man i en annen studie fra England fant $\emptyset \mathrm{kt}$ risiko for død ved hjertesvikt og iskemisk hjertesykdom hos begge kjønn og ved atrieflimmer hos kvinner (5). I vår studie kunne vi ikke påvise forskjeller mellom kjønn for diagnoseundergrupper, da det ved stratifiserte analyser ble få dødsfall i hver av gruppene og resultatene således ble for usikre. Antallet døde er relativt lavt i vår studie, og vi kan derfor ikke utelukke at de inkluderte hjerte- og karsykdommene ut over hjerneslag er uavhengige risikofaktorer for død etter covid-19 (jamfør vide konfidensintervall, tabell 3).

I en nylig publisert oversiktsartikkel der man har sett på kliniske karakteristika hos kreftpasienter med covid-19, var kreft, etter å ha tatt hensyn til alder og annen komorbiditet, ikke en uavhengig risikofaktor for $\mathrm{d} ø \mathrm{~d}(\underline{11})$. Dette er i overensstemmelse med resultatene fra vår studie for kreft samlet i alle stadier (data ikke vist). Vi fant imidlertid en signifikant forhøyet risiko for død ved kreftsykdom med fjernspredning på diagnosetidspunktet. Pasienter med metastaser på diagnosetidspunktet har en dårligere prognose og funksjonstilstand enn pasienter uten dette, og de gjennomgår ofte mer intensiv behandling med kjemoterapi enn andre kreftpasienter. Denne gruppen kan derfor ha forhøyet risiko for alvorlig forløp av covid-19. Behandling med kjemoterapi har tidligere blitt identifisert som en mulig risikofaktor for $\mathrm{d} ø \mathrm{~d}$ (5). I vår studie manglet vi informasjon om krefttype og gjennomgått behandling, så det var ikke mulig å si noe spesifikt om hvilke grupper av kreftpasientene som hadde forhøyet risiko for død etter covid-19. Det er også ønskelig å gjenta våre analyser med et større datagrunnlag på grunn av få observasjoner av kreft med metastaser på diagnosetidspunktet. En eventuell foreliggende feilklassifisering av stadium eller dødsårsak for disse pasientene ville kunne påvirke resultatene.

Etter å ha tatt hensyn til andre tilgjengelige risikofaktorer viste våre resultater at risiko for $\mathrm{d} ø \mathrm{~d}$ var betydelig $\emptyset \mathrm{kt}$ for aldersgruppene 60 år og eldre sammenlignet med gruppene under 60 år. Den beregnede absolutte risiko for $\mathrm{d} ø \mathrm{~d}$ for en person uten noen av de registrerte sykdommene som var inkludert i vår studie, var på 0,17\% for personer under 60 år, 2,1 \% for personer 6o-69 år og 7,8 \% for personer 70-79 år. Resultatene i vår studie samsvarer godt med funn fra Danmark, der letaliteten hos personer uten andre sykdommer var under $5 \%$ for de under 80 år ( $\underline{6})$. 
Vi fant at menn hadde $50 \%$ (alle aldersgrupper) til $70 \%$ ( $<85$ år) økt risiko for død sammenlignet med kvinner etter justering for alder og andre risikofaktorer. Dette er i tråd med funn fra mange tidligere studier $(3,4, \underline{12}, \underline{13})$. Det har vært diskutert om forskjeller i immunologisk respons mellom kjønnene kan være en av årsakene til dette (14). Det har også vært diskutert om større alkoholinntak blant menn enn kvinner kan være årsak til kjønnsforskjellene, men resultatene fra studier som har forsøkt å korrigere for dette, har ikke funnet alkohol som konfunderende faktor (13).

I Norge var andelen døde av de diagnostiserte (letaliteten) på totalt 3,0 \% i studieperioden. Det er stor variasjon i rapportert letalitet fra ulike land og pasientpopulasjoner. I studier fra Kina, Danmark og Italia er det rapportert letalitet på henholdsvis 2,3 \%, 5,2 \% og 7,2 \% (므, 15). Hovedforklaringen på at Italia hadde svært høy letalitet, var en svært høy andel eldre blant de påvist smittede. I tillegg til behandlingsrelaterte forskjeller kan forskjellige teststrategier og ulike definisjoner av covid-19-relaterte dødsfall medføre forskjeller i rapportert letalitet mellom land. Letaliteten kan også endre seg betydelig over tid som følge av endringer i testpraksis, alderssammensetning og behandling. I Norge var det på grunn av lav testkapasitet i første del av pandemien mange syke som ikke ble testet. Fra august $\varnothing$ kte testaktiviteten betydelig, og man fanget dermed opp en større andel av de smittede. I tillegg sank gjennomsnittsalderen blant de smittede. Hovedsakelig som en følge av dette, samt en sannsynlig forbedret behandling, har den beregnede letaliteten i Norge gått ned. Dersom vi gjør et grovt anslag ut fra totalt antall smittede per 8.11.2020 (25 520) og døde per 8.12.2020 (361), er letaliteten for Norge for hele perioden fra februar frem til desember ca. $1,4 \%$.

Styrken i vår studie er at vi ser på risiko for død for en hel nasjonal populasjon med SARSCoV-2-testpositive personer. De fleste studier, med unntak av Reilev og medarbeidere fra Danmark (ㅁ), har omhandlet risikofaktorer i selekterte pasientgrupper og kan derfor ikke si noe sikkert om risiko for $\mathrm{d} ø \mathrm{~d}$ av covid-19 for personer med underliggende sykdommer i befolkningen generelt (16). De inkluderte testpositive personene i vår studie kan også være noe selekterte som følge av at testkriteriene i studieperioden kan ha gitt større sannsynlighet for testing av personer med underliggende sykdommer enn av friske personer. Resultatene fra en tidligere studie på samme pasientmateriale fra Norge fant imidlertid at det var små forskjeller i forekomst av underliggende sykdomstilstander mellom personer som hadde testet positivt for covid-19 og befolkningen generelt (17.). $\AA$ sammenligne totaldødeligheten i en testpositiv gruppe med totaldødelighet i en testnegativ kontrollgruppe vil i fremtidige studier kunne gi ytterligere informasjon om betydningen av ulike risikofaktorer for dødelighet av covid-19.

Våre data på sykdommer ut over hjerte- og karsykdommer og kreft er mangelfulle. Hjerteog karregisteret inneholder kun informasjon om andre sykdommer fra samme opphold/episode som det foreligger en hjerte- og karrelatert diagnose. Det er nærliggende å tro at de på sykehus med flere diagnoser samtidig med en hjerte- og kardiagnose, er de mest alvorlige tilfellene. Disse opplysningene er således nyttige for å kunne justere for sykeligheten til pasientene for å få mer korrekte estimater for de andre faktorene i analysemodellene. Betydningen av komorbiditet ut over hjerte- og karsykdommer og kreft for dødeligheten etter påvist covid-19 i Norge bør undersøkes i fremtidige studier med mer komplett informasjon om andre sykdommer.

Den største risikofaktoren for død blant SARS-CoV-2-testpositive personer fra første halvår 2020 var alder. Mannlig kjønn, tidligere påvist hjerneslag og kreft med fjernspredning var også assosiert med høyere risiko for død etter påvist covid-19. Det er behov for nye studier for å kartlegge betydningen av krefttype for dødeligheten etter påvist covid-19 i Norge.

Artikkelen er fagfellevurdert. 


\section{LITTERATUR}

1. Kuderer NM, Choueiri TK, Shah DP et al. Clinical impact of COVID-19 on patients with cancer (CCC19): a cohort study. Lancet 2020;395:1907-18. [PubMed][CrossRef]

2. Petrilli CM, Jones SA, Yang J et al. Factors associated with hospital admission and critical illness among 5279 people with coronavirus disease 2019 in New York City: prospective cohort study. BM] 2020;369: m1966. [PubMed][CrossRef]

3. Williamson EJ, Walker AJ, Bhaskaran K et al. Factors associated with COVID-19-related death using OpenSAFELY. Nature 2020; 584: 430-6. [PubMed][CrossRef]

4. Barron E, Bakhai C, Kar P et al. Associations of type 1 and type 2 diabetes with COVID-19-related mortality in England: a whole-population study. Lancet Diabetes Endocrinol 2020; 8: 813-22. [PubMed] [CrossRef]

5. Clift AK, Coupland CAC, Keogh RH et al. Living risk prediction algorithm (QCOVID) for risk of hospital admission and mortality from coronavirus 19 in adults: national derivation and validation cohort study. BMJ 2020; 371: m3731. [PubMed][CrossRef]

6. Reilev M, Kristensen KB, Pottegård A et al. Characteristics and predictors of hospitalization and death in the first 11122 cases with a positive RT-PCR test for SARS-CoV-2 in Denmark: a nationwide cohort. Int J Epidemiol 2020; 49: dyaa140. [PubMed][CrossRef]

7. Gulseth HL, Helland E, Johansen KI et al. Dødsfall etter påvist SARS-CoV-2 i Norge. Tidsskr Nor Legeforen 2020; 140. doi:10.4045/tidsskr.20.0693. [CrossRef]

8. Folkehelseinstituttet. Foreløpige tall for covid-19-assosierte dødsfall i Dødsårsaksregisteret. https://www.fhi.no/hn/helseregistre-og-registre/dodsarsaksregisteret/forelopige-tall-for-covid-19assosierte-dodsfall-i-dodsarsaksregisteret/ Lest 16.11.2020.

9. Tehrani S, Killander A, Åstrand P et al. Risk factors for death in adult COVID-19 patients: Frailty predicts fatal outcome in older patients. Int J Infect Dis 2020; 102: 415-21. [PubMed][CrossRef]

10. Himmels JPW, Borge TC, Brurberg KG et al. COVID-19 and risk factors for hospital admission, severe disease and death. A rapid review -3rd update. Oslo: Folkehelseinstituttet, 2020. https://www.fhi.no/publ/2020/covid-19-og-risikofaktorer-for-sykehusinnleggelse-alvorlig-sykdom-ogdod/ Lest 16.11.2020.

11. Zhang $\mathrm{H}$, Han $\mathrm{H}$, He T et al. Clinical characteristics and outcomes of COVID-19-infected cancer patients: A systematic review and meta-analysis J Natl Cancer Inst 2020; 112: djaa168. [PubMed] [CrossRef]

12. Gupta S, Hayek SS, Wang W et al. Factors associated with death in critically ill patients with coronavirus disease 2019 in the US. JAMA Intern Med 2020; 180: 1-12. [PubMed][CrossRef]

13. Kragholm K, Andersen MP, Gerds TA et al. Association between male sex and outcomes of Coronavirus Disease 2019 (Covid-19) - a Danish nationwide, register-based study. Clin Infect Dis 2020; 71: ciaa924. [PubMed][CrossRef]

14. Conti P, Younes A. Coronavirus COV-19/SARS-CoV-2 affects women less than men: clinical response to viral infection. J Biol Regul Homeost Agents 2020;34:339-43. [PubMed]

15. Onder G, Rezza G, Brusaferro S. Case-fatality rate and characteristics of patients dying in relation to COVID-19 in Italy. JAMA 2020; 323: 1775-6. [PubMed][CrossRef]

16. Griffith GJ, Morris TT, Tudball MJ et al. Collider bias undermines our understanding of COVID-19 disease risk and severity. Nat Commun 2020; 11: 5749. [PubMed][CrossRef]

17. Nystad W, Hjellvik V, Larsen IK et al. Underliggende tilstander hos voksne med covid-19. Tidsskr Nor Legeforen 2020; 140. doi: 10.4045/tidsskr.20.0512. [PubMed][CrossRef]

Publisert: 29. desember 2020. Tidsskr Nor Legeforen. DOI: 10.4045/tidsskr.20.0956

Mottatt 23.11.2020, første revisjon innsendt 9.12.2020, godkjent 11.12.2020.

Publisert under åpen tilgang CC BY-ND. Lastet ned fra tidsskriftet.no 26. april 2023. 